\title{
Remarkably Consistent Rare Earth Element Grades at Round Top Yttrofluorite Deposit
}

\author{
Nicholas E. Pingitore Jr. ${ }^{1 *}$, Juan W. Clague ${ }^{2}$, Daniel Gorski ${ }^{3}$ \\ ${ }^{1}$ Department of Geological Sciences, The University of Texas at El Paso, El Paso, TX, USA \\ ${ }^{2}$ Environmental Engineering \& Public Health, LLC, El Paso, TX, USA \\ ${ }^{3}$ Texas Mineral Resources Corporation, Sierra Blanca, TX, USA \\ Email: *npingitore@utep.edu
}

How to cite this paper: Pingitore Jr., N.E., Clague, J.W. and Gorski, D. (2018) Remarkably Consistent Rare Earth Element Grades at Round Top Yttrofluorite Deposit. Advances in Materials Physics and Chemistry, 8, 1-14.

https://doi.org/10.4236/ampc.2018.81001

Received: November 21, 2017

Accepted: January 6, 2018

Published: January 9, 2018

Copyright $\odot 2018$ by authors and Scientific Research Publishing Inc. This work is licensed under the Creative Commons Attribution International License (CC BY 4.0).

http://creativecommons.org/licenses/by/4.0/ (c) (i) Open Access

\begin{abstract}
The peraluminous rhyolite that forms Round Top Mountain (approximately 375 $\mathrm{m}$ high $\times$ nearly $2 \mathrm{~km}$ in diameter), near Sierra Blanca, Hudspeth County, west Texas, USA, is enriched in yttrium and heavy rare earth elements (YHREEs), as well as Li, Be, U, Th, Sn, F, Rb, Cs, Nb, and Ta. Texas Mineral Resources Corp. (USA) proposes to release the YHREEs from their unique yttrofluorite host via heap leaching with dilute sulfuric acid. The inexpensive process also releases portions of valuable byproduct $\mathrm{Be}, \mathrm{Li}$, and $\mathrm{U}$ from accessory minerals amid the insoluble feldspars and quartz that comprise $90 \%-95 \%$ of the surface-exposed rhyolite mountain. The objective of this study is to determine the consistency of mineralization grade, an important consideration in mine planning and preliminary economic analysis. The method is to plot elemental analyses of $\mathrm{Y}, \mathrm{Dy}, \mathrm{Ho}, \mathrm{Tm}, \mathrm{Yb}, \mathrm{Ce}, \mathrm{Pr}, \mathrm{Nd}, \mathrm{Eu}, \mathrm{Gd}, \mathrm{Tb}, \mathrm{U}$, and $\mathrm{Nb}$ from more than 1400 reverse circulation cuttings taken from 64 exploration drill holes against sample depth. The result of inspection of the plots reveals a remarkably homogeneous distribution of minor and trace elements throughout the sampled portion of the massive, 1.6-billion-tonne laccolith. The plots drive the conclusion that Round Top mine feedstock should remain constant for the life of the mine (multiple decades). Thus mining mechanics could be optimized at the start of operations and not require expensive later changes. The physical and chemical design of the heap leach and recovery and purification of target elements from pregnant leach solution also could be perfected during early development.
\end{abstract}

\section{Keywords}

Heavy Rare Earth Elements, Deposit Grade, Round Top Mountain, Heap Leach, Mineral Processing 


\section{Introduction}

The rare earth elements (REEs) are non-replaceable ingredients in many current and emerging critical technologies including lasers, high-strength permanent magnets, optical fibers, catalysts, fuel cells, high-strength alloys, specialty glass, opto-electronics, and so forth. Such everyday necessities as cell phones and cordless power tools would not exist without the REEs [1] [2] [3] [4] [5]. Security of the REE supply chain has become an issue for such nations as the United States that do not have significant domestic mining or recycling operations, particularly in light of geopolitical fluctuations [6] [7]. Pollution from mining operations presents another uncertainty about future supplies, particularly for the heavy REEs (HREEs) [8] [9] [10] [11] [12].

Among the REEs, yttrium and the HREEs (YHREEs) are especially scarce and precious. Most are won from the ion adsorption clays of south China, with minor amounts from the other four of the "big five" REE deposit types: bastnaesite, monazite, xenotime, and apatite ores. These five provide virtually all, more than 95\%, of global REE extraction supply [13] [14] [15] [16] [17].

There is a little known but potentially bountiful source of YHREEs hosted in yttrofluorite, a variety of the mineral fluorite $\left(\mathrm{CaF}_{2}\right.$, isometric) with significant yttrium and HREE content. In yttrofluorite the trivalent $\left(3^{+}\right) \mathrm{Y}$ and HREEs substitute for from $5 \%$ to $30 \%$ of the bivalent $\mathrm{Ca}^{2+}$ cations, yielding the formula $\left(\mathrm{Ca}_{1-\mathrm{x}} \mathrm{Y}, \mathrm{HREE}_{\mathrm{x}}\right) \mathrm{F}_{2+\mathrm{x}}[18]$.

The only currently known yttrofluorite YHREE deposit is Round Top Mountain, located near the town of Sierra Blanca in Hudspeth County, west Texas, USA [19]. The mountain is a rhyolite laccolith, a mushroom-shaped igneous intrusion that formed when magma pushed its way upward toward the earth's surface and spread out between older flat lying rock units. Subsequent erosion of the weaker overlying rocks has exposed most of the laccolith as a mountain nearly $2 \mathrm{~km}$ in diameter and over $375 \mathrm{~m}$ high [20] [21]. The Texas Bureau of Economic Geology has estimated the mass of the rhyolite at some 1.6 billion tonnes and TMRC has estimated the inferred mineral resource at $430,000,000 \mathrm{~kg}$ of rare earth oxide in the drilled portion of the mountain [21] [22].

Geochemically the rhyolite is peraluminous $\left(\mathrm{Al}_{2} \mathrm{O}_{3}>\mathrm{Na}_{2} \mathrm{O}+\mathrm{K}_{2} \mathrm{O}+\mathrm{CaO}\right)$ and is enriched in rare earth elements (REEs) to a level of just over $500 \mathrm{ppm}$ [22]. Strikingly, YHREEs comprise some $72 \%$ of the total REEs (TREEs), a level of enrichment in YHREEs rarely encountered in igneous rocks. The rhyolite also is enriched in other incompatible elements (those whose charge and size restrict their incorporation in many common mineral structures), including $\mathrm{Be}, \mathrm{Li}, \mathrm{Sn}, \mathrm{Rb}, \mathrm{Cs}$, $\mathrm{Ga}, \mathrm{Nb}, \mathrm{Ta}, \mathrm{U}$, and $\mathrm{Th}[22]$. The rhyolite has been dated radiometrically at $36 \mathrm{Ma}$ (million years), corresponding to the Late Eocene geologic Epoch [23].

In consideration of the massive size of the deposit, the enrichment in valuable YHREEs, and the laboratory demonstration that the host mineral, yttrofluorite, is soluble in dilute sulfuric acid, Texas Mineral Resources Corporation has proposed to extract the YHREEs and byproduct elements by heap leach with dilute $\mathrm{H}_{2} \mathrm{SO}_{4}$ 
[19] [22] [24] [25]. Because the deposit is exposed at the surface there is little overburden to be excavated before surface mining could begin. Furthermore, the Round Top rhyolite has proved both porous and permeable, making high leach YHREE recoveries, up to $90 \%$, possible without fine grinding [26]. It also is important to note that the YHREEs at Round Top present a compact, 3-dimensional mining opportunity. This geometry limits potential environmental degradation chiefly to the footprint of the part of the mountain being excavated, the crushing site, and the heap leach pile(s). This stands in sharp contrast with the essentially 2-dimensional aspect of the south China ion-adsorption deposits. There, in situ surface mining can degrade large areas in the caustic leaching of relatively thin layers of soil and overburden crusts.

An important consideration in any mining project is the consistency of the grade of the deposit [27] [28] [29]. From an economic planning perspective an even grade throughout a deposit makes it much simpler to model and predict mining performance. A constant deposit and feedstock grade implies no changes in the target mineralogy and no changes in the target-mineralogy-to-gangue ratio. Thus, the mining process could be optimized just once, at the start of operations. Furthermore, additional separation and purification processes would need to be optimized only once. In effect, an even grade of ore throughout the life of the mine allows the endeavor to operate more like a factory than a typical mine. In this contribution we document the remarkably consistent grade of YHREEs and other incompatible elements through the large sampled portion of Round Top Mountain.

\section{Materials and Methods}

\subsection{Field Sampling of Rhyolite}

To delineate the extent and grade of the deposit, in 2011 Texas Rare Earth Resources Corporation (TRER), now with a new name, Texas Mineral Resources Corporation (TMRC), drilled a series of 5.25-inch (13-cm) diameter reverse circulation (RC) holes into the mountain for a total length of 26,915 feet (8204 m) [24]. They cored two more holes, drilled parallel to $2 \mathrm{RC}$ holes to confirm composition. The RC cuttings were collected from 5 -foot $(1.5 \mathrm{~m})$ intervals and stored in sample bags sealed in plastic buckets.

Borehole locations are seen in Figure 1. The drill holes south of the blue line on the map were not included in this study. These were drilled on the southern flanks of the mountain, which can have an extensive erosional cover. That material no longer maintains the same elemental or mineralogical composition as the bulk rhyolite due to physical and chemical weathering and selective removal of minerals by erosion. Picking the boundary between the eroded material and the bulk rhyolite with certainty was not possible from the borehole log records, so we chose to censor the list of holes and eliminate these holes from our analysis. A total of 1671 samples from 66 drill holes was then available for study. 


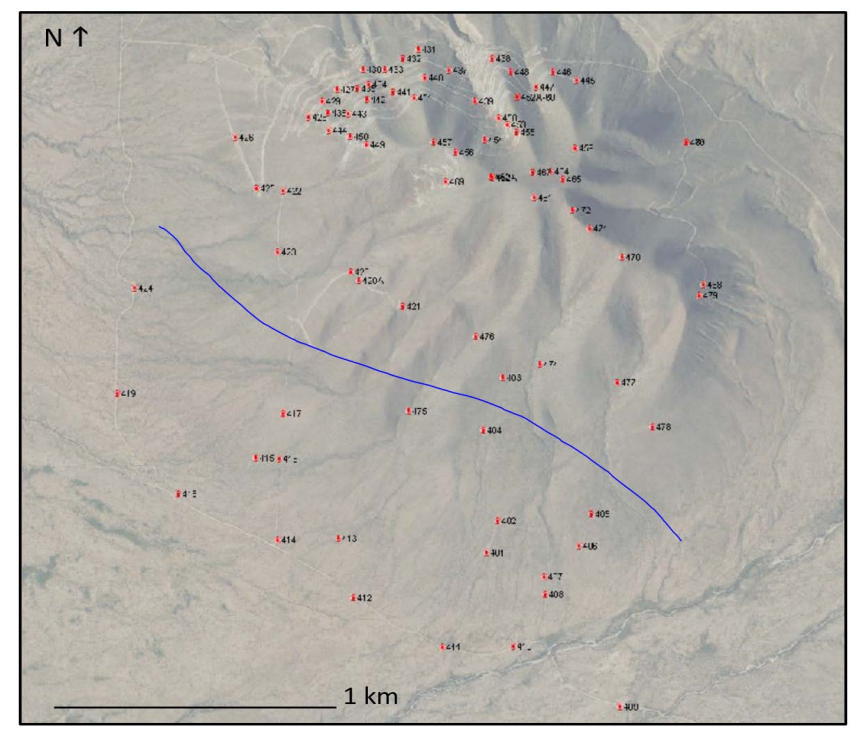

Figure 1. Round Top Mountain drill sites. Sites below the blue line were not included in our analysis. Drainage pattern and topography show that these lie on alluvial fan material, with several even beyond the lateral extent of the laccolith.

\subsection{Laboratory Determination of Elemental Concentrations}

A 1-kg sample was created from each 5-foot (1.5-m) interval of each drill hole for laboratory determination of 38 minor and trace elements. As results were received by TMRC that indicated overall uniform elemental concentrations, the 5-foot (1.5-m) sample intervals were composited into 10- to 30-foot (3- to 6.1-m) intervals, based on the lithologies determined from the borehole logs.

Multi-element analyses were performed by ICP-MS (inductively coupled plasma mass spectrometry) at ALS Chemex, a certified analytical laboratory in Vancouver, British Columbia, Canada. Duplicates, blanks, and standards were included in the sample stream at appropriate intervals. Additional details of the entire drilling and analysis programs can be found in the TMRC Preliminary Economic Assessment document [24].

\subsection{Data Presentation}

Figure 2, top, presents yttrium content in ppm, $\mathrm{x}$-axis, versus elevation (MSL, i.e., relative to mean sea level), y-axis, of drill cuttings from the 66 selected drill holes. A total of 1671 samples are plotted, each color-coded to its drill hole, labelled on right side of the figure. Bottom left diagram, labelled “-1", eliminates the highest and lowest cutting from each drill hole. Those cuttings typically were contaminated by contact with the overlying and underlying strata during emplacement of the Round Top laccolith. The hot magma melts portions of the surrounding containing rock, yielding a mixed contact zone that no longer reflects the overall composition of the laccolith. The third graph, at bottom right, shows elimination of the uppermost and lowermost two drill cutting samples from each hole. Low concentration outliers are seen to be removed progressively 


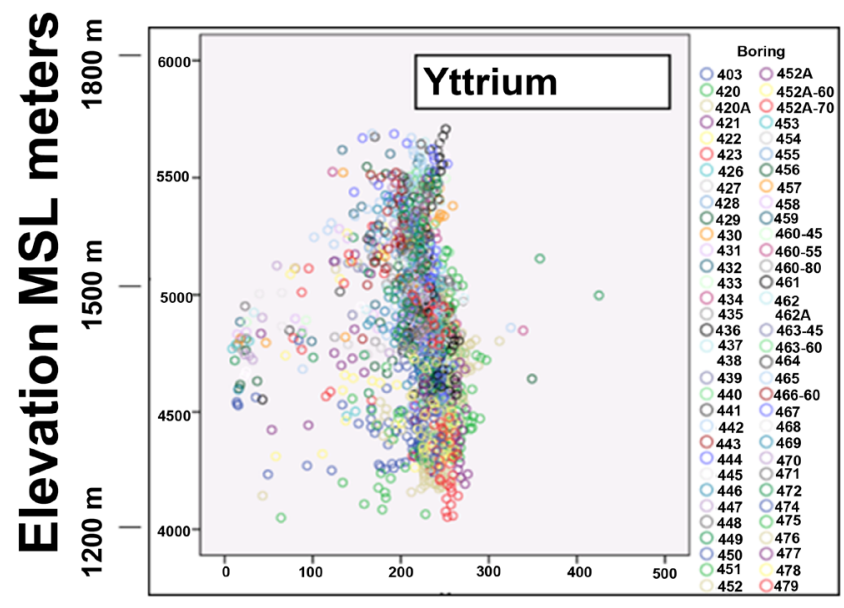

Concentration (ppm)

(a)

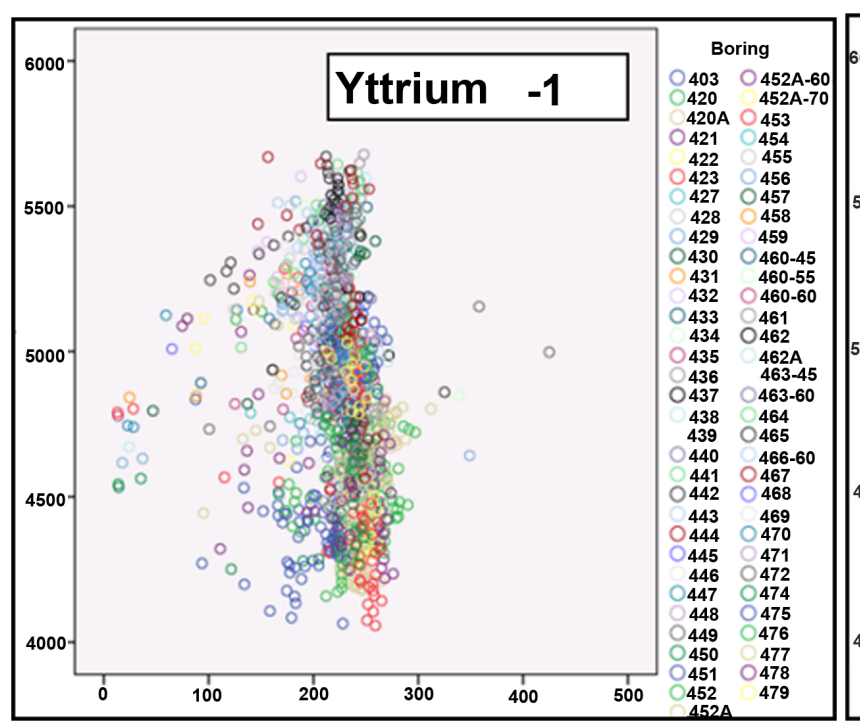

(b)

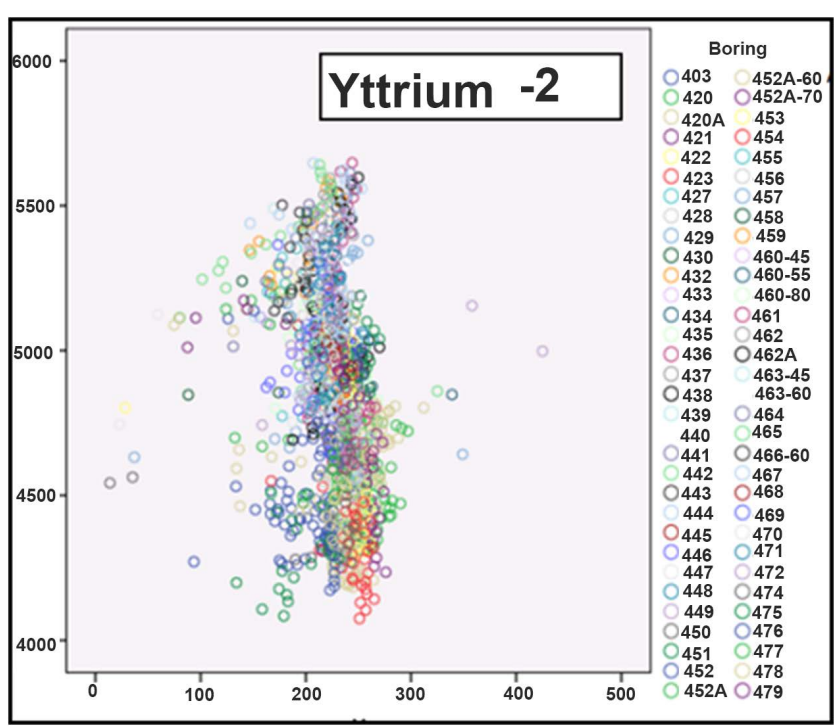

(c)

Figure 2. Top: Yttrium content in ppm of 1671 samples from 66 drill holes plotted versus elevation at Round Top Mountain. Drill holes color-coded at right. Elevation scale, taken from drill hole logs, ranges from 4000 to 6000 feet, or approximately 1220 to 1830 m. MSL = mean sea level. Bottom Left: Same plot after removing top and bottommost samples (“-1" label) from each hole, which likely were contaminated and diluted in Y content by contact of magma with enclosing country rock. Bottom Right. Same plot after removing 2 uppermost and bottommost samples ("-2" label) from each hole. Note elimination of mostly low concentration outliers in this process. All subsequent plots are of this " -2 " type, with 1408 samples.

by this process. Thus, the plot labeled -2 best characterizes the elemental variation of the bulk of the deposit. If Round Top were to be open "pit" mined (or more properly stated, cut down from the top), only the minor upper contact zone would be lower grade material that might be discarded rather than processed. Later excavation would not continue into the lower contact zone. Note that after elimination of the 4 bounding samples from each well, a total of 1408 samples were plotted, and two very short drill holes from which only a total of 7 samples had been recovered were eliminated. The rest of the plots, seen in Figure 3 and Figure 4, are all of the "-2" type, with 1408 samples. 

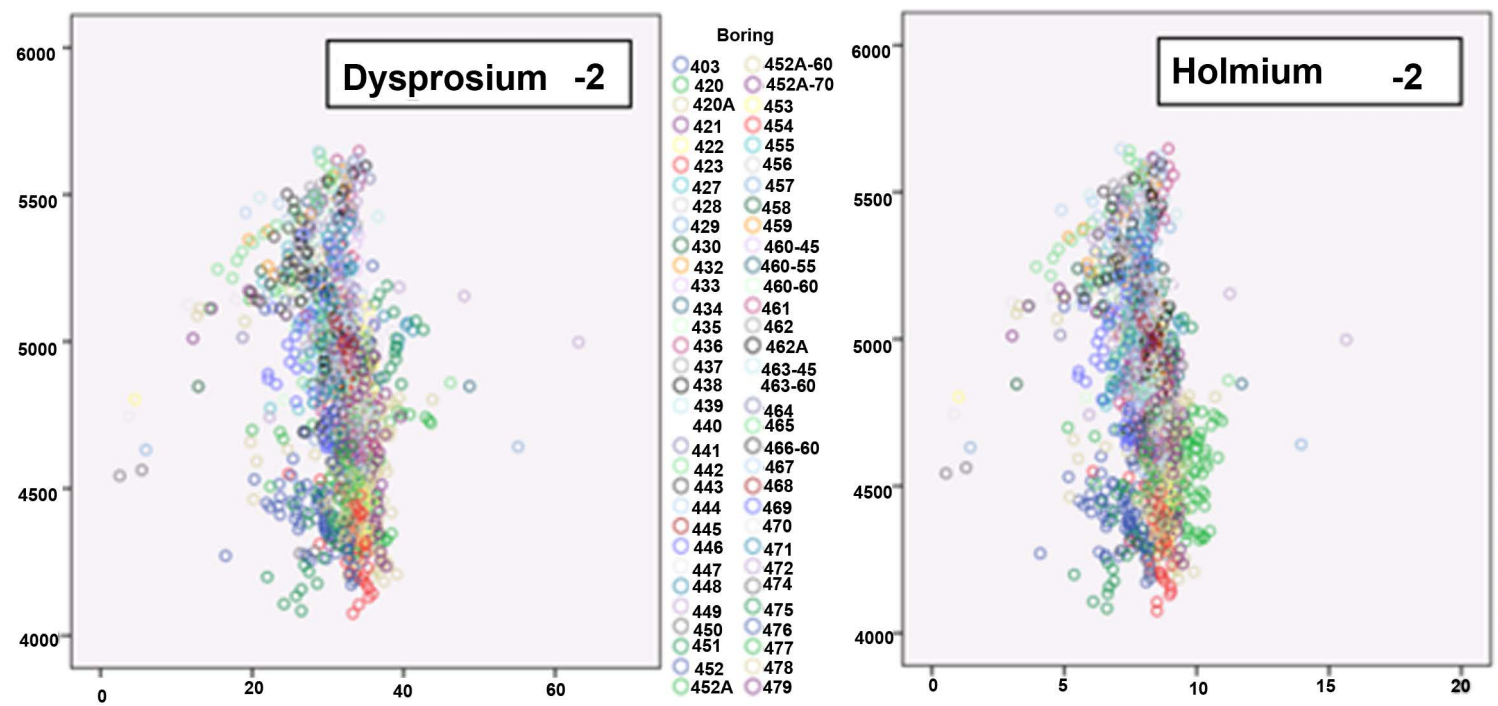

Boring

$\begin{array}{rr}403 & 452 \mathrm{~A}-60 \\ 420 & 452 \mathrm{~A}-70\end{array}$

$420 \mathrm{~A} \quad 453$

$421 \bigcirc 454$

$\begin{array}{ll}422 & 455 \\ 423 & 456\end{array}$

$\begin{array}{rr}427 & 457 \\ 428 & 458\end{array}$

$429 \quad 459$

$\begin{array}{ll}430 & 460-45 \\ 432 & 460-55\end{array}$

$\begin{array}{ll}433 & 460-60 \\ 434 & 461\end{array}$

$\begin{array}{ll}434 & 461 \\ 435 & 462\end{array}$

$\begin{array}{ll}437 & 463-45 \\ 438 & 463-60\end{array}$

439464

$440 \quad 465$

$\begin{array}{lll}441 & 466-60 \\ 4467 & 4 & \end{array}$

442
443 $\quad 468$

$\begin{array}{ll}444 & 469 \\ 445 & 470\end{array}$

$445 \quad 470$

$\begin{array}{ll}446 & 471 \\ 447 & 472 \\ 448 & 474\end{array}$

$449 \quad 475$

$\begin{array}{ll}449 & 475 \\ 450 & 476\end{array}$

$452 \quad 478$
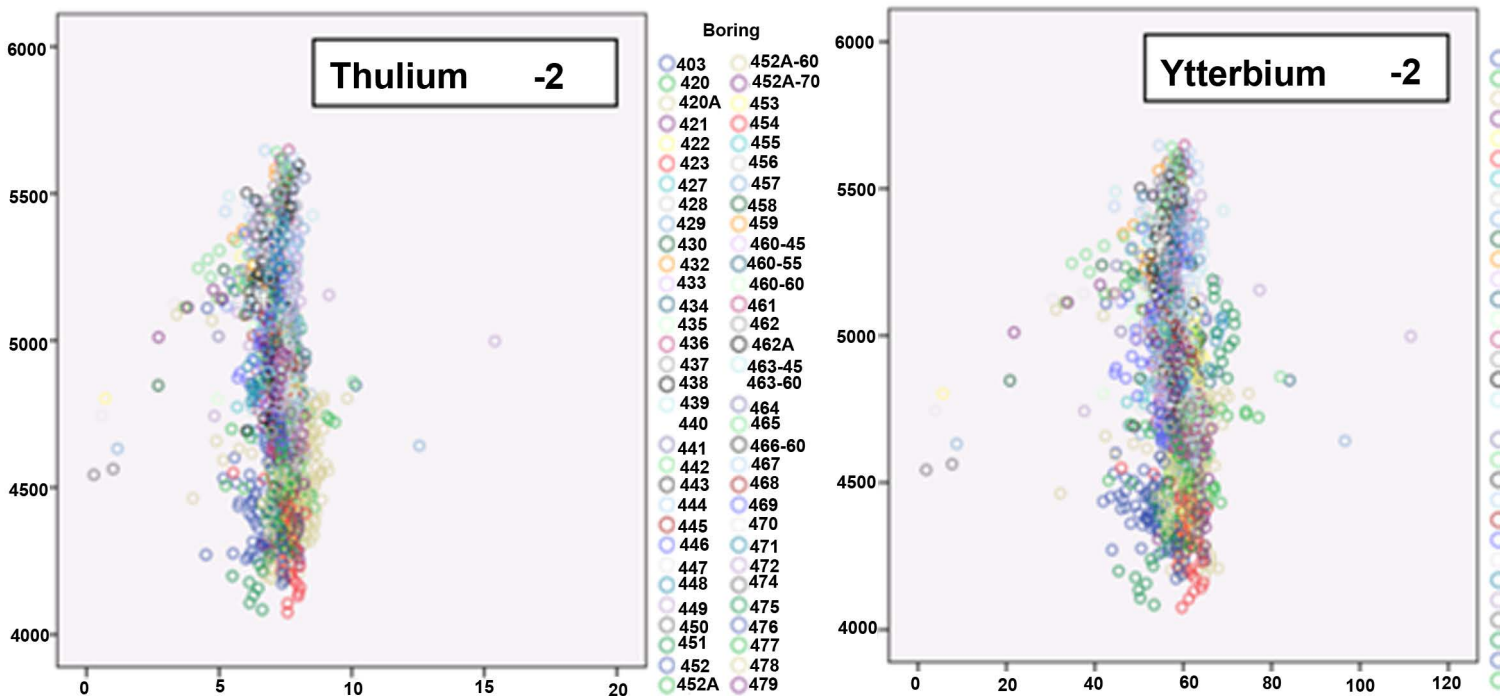

Boring

$\begin{array}{ll}403 & 452 \mathrm{~A}-60 \\ 420 & 452 \mathrm{~A}-70\end{array}$

$420 \mathrm{~A} \quad 453$

$\begin{array}{ll}420 \mathrm{~A} & 453 \\ 421 & 454\end{array}$

$\begin{array}{ll}422 & 455 \\ 423 & 456\end{array}$

$427 \quad 457$

428
429
$\quad 459$

$\begin{array}{ll}429 & 459 \\ 430 & 460-45\end{array}$

$\begin{array}{rr}430 & 460-45 \\ 432 & 460-55\end{array}$

$433 \quad 460-60$

$434 \quad 461$

$436 \bigcirc 462 A$

$\begin{array}{ll}437 & 463-45 \\ 438 & 463-60\end{array}$

$439 \quad 464$

$440 \quad 465$

$442 \quad 467$
442

$\begin{array}{rr}444 & 469 \\ 445 & 470\end{array}$

$446 \quad 471$

$\begin{array}{ll}447 & 472 \\ 448 & 474\end{array}$

$\begin{array}{ll}449 & 475 \\ 450 & 476 \\ 451 & 477\end{array}$

$\begin{array}{ll}451 & 477 \\ 452 & 478\end{array}$
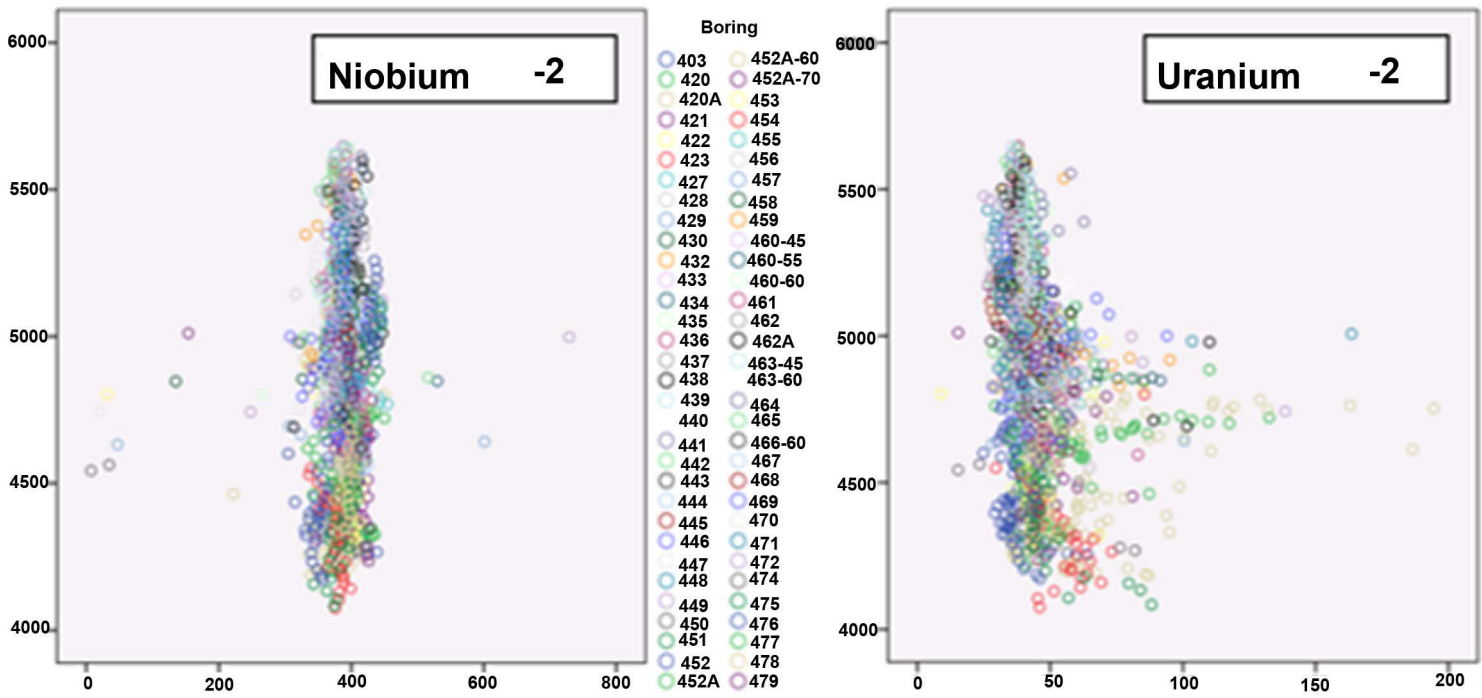

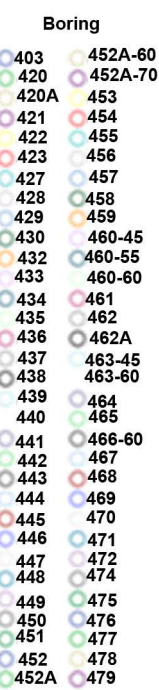

Figure 3. Plots of HREEs Dy, Ho, Tm, and $\mathrm{Yb}$, and $\mathrm{Nb}$ and $\mathrm{U}$ content in ppm versus elevation at Round Top Mountain. Drill holes color-coded at right. Elevation scale, taken from drill hole logs, ranges from 4000 to 6000 feet, or approximately 1220 to $1830 \mathrm{~m}$. 

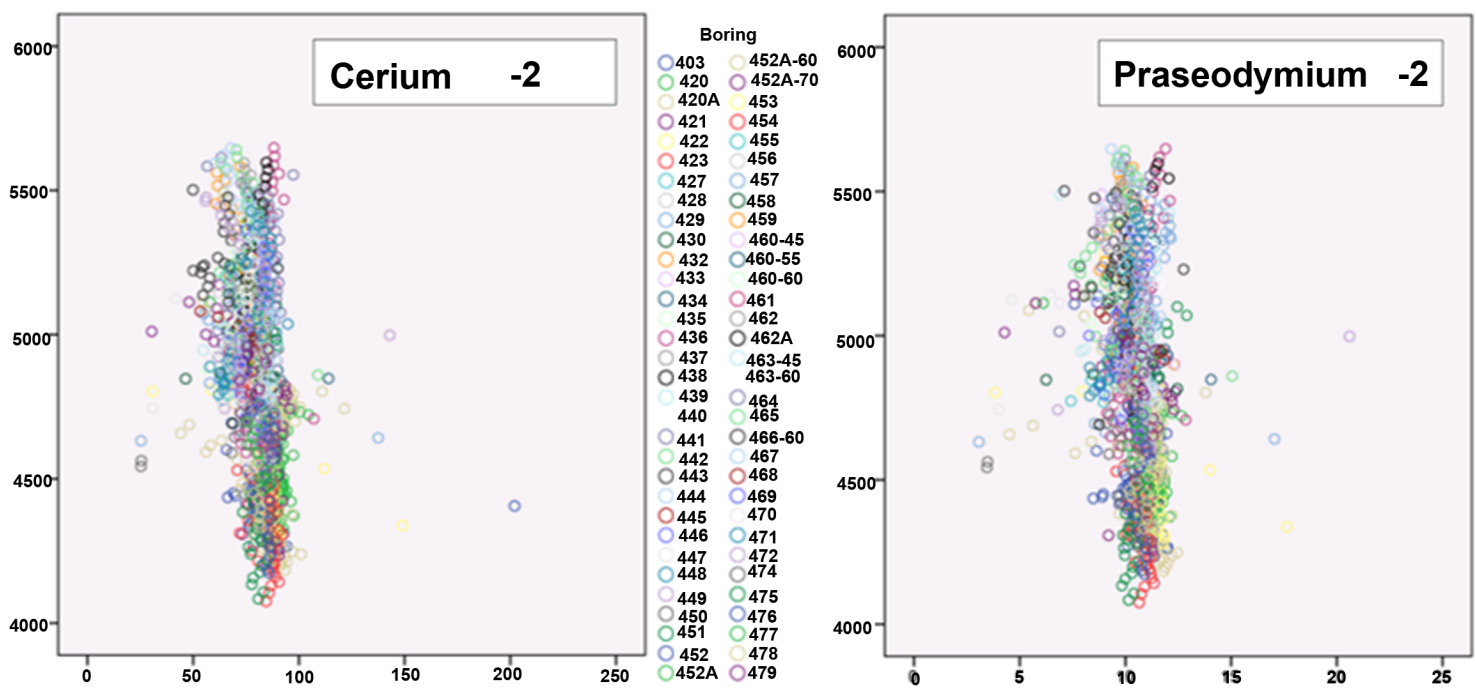

Boring
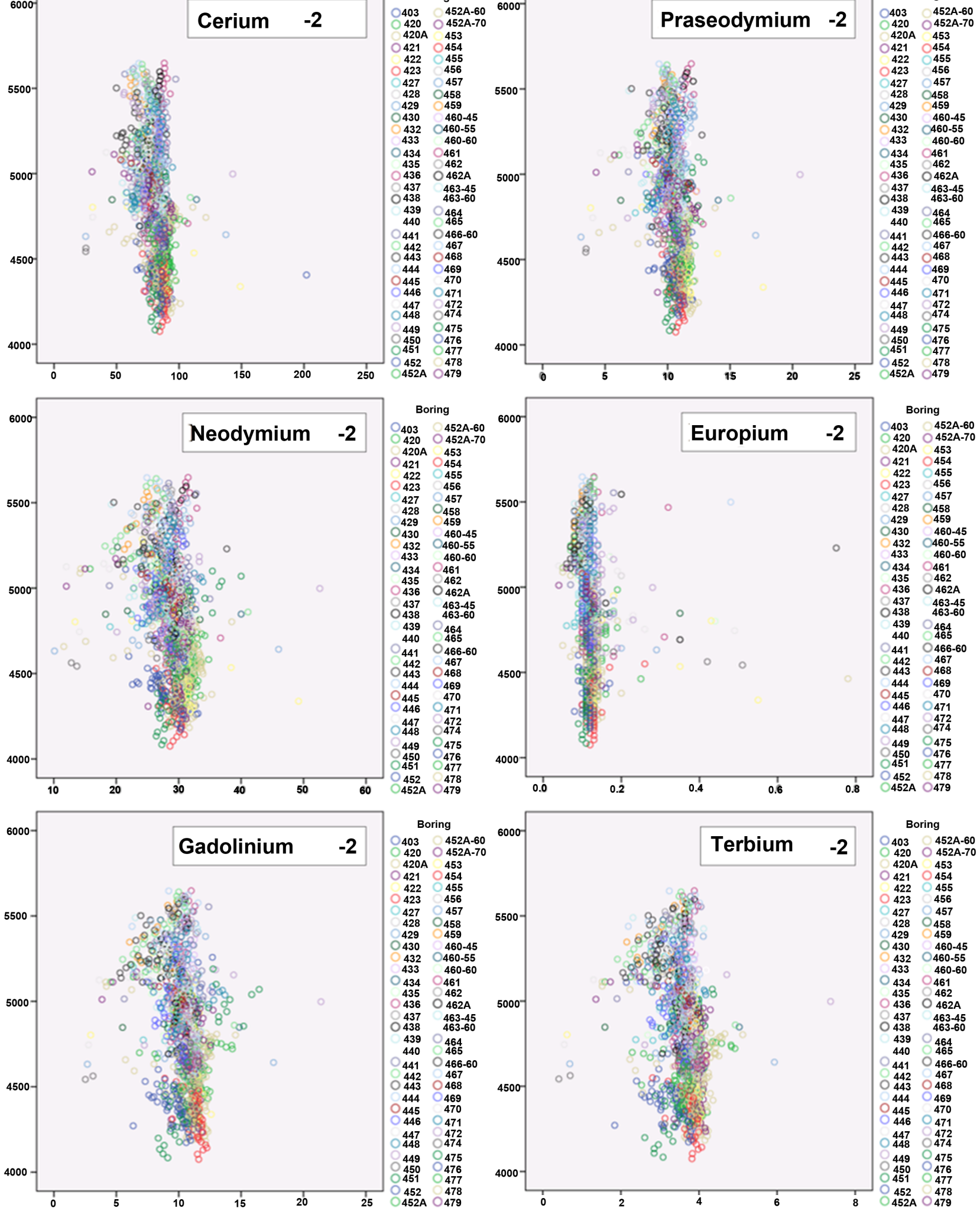

Figure 4. Plots of LREEs Ce, Pr, Nd, and Eu, and HREEs Gd and Tb contents in ppm versus elevation at Round Top Mountain. Drill holes color-coded at right. Elevation scale, taken from drill hole logs, ranges from 4000 to 6000 feet, or approximately 1220 to $1830 \mathrm{~m}$. 


\section{Results and Discussion}

\subsection{REE Grades}

Figure 3 presents graphs of concentrations of the HREEs Dy, Ho, Tm, and $\mathrm{Yb}$ and of the incompatible elements $\mathrm{Nb}$ and $\mathrm{U}$ versus depth. Figure 4 shows similar graphs for LREEs Ce, Pr, Nd, Eu, and HREEs Gd and Tb.

A scan of all the graphs reveals a limited range of variation for every element, with a limited number of positive and negative outliers. Despite the censoring of the uppermost and lowermost samples from each drill hole, there still are more negative than positive outliers. This suggests that contact zone contamination, with mixing in of the country rock and dilution of the laccolith, may have extended even farther into the rhyolite. It also is likely that weathering of the rhyolite and selective dissolution of soluble minerals removes some of these elements along the fractures and joints found throughout the bulk rhyolite.

To further emphasize the consistency of REE grades, note that for Y (Figure 2) nearly all the samples fall between 200 and $270 \mathrm{ppm}$. Thus, they fall within $+/-35 \mathrm{ppm}$ of the visual range average of $235 \mathrm{ppm}$. That is a variation of $+/-$ $15 \%$, more remarkable still if one considers that the reproducibility for a single sample likely is at least $+/-5 \%$ due to sample preparation and instrument analysis. The element $\mathrm{Y}$ was chosen for this analysis because it by far is the most abundant REE in Round Top, 4 times more than Yb, the next most abundant. It therefore was likely to have the least sample preparation and analytical error and thus its distribution would best demonstrate natural REE variation in the deposit.

A number of the graphs appear to show a very slight enrichment in REEs with depth in Round Top Mountain. There is a barely perceptible negative slope in the central, dense set of data points, ignoring the peripheral outliers. From a mining standpoint the possible enrichment is not an economic or technical consideration; it falls well within the small range of variation seen at any depth.

Figure 5 confirms the slight enrichment in some REEs with depth at Round Top. The box symbol, average concentration of the element in the lower half of the laccolith, plots slightly above the diamond symbol, upper half average. The figure also demonstrates that there is little difference in concentrations of most elements between the upper and lower sections of the deposit.

These graphs (Figures 2-4) attempt to portray the variability of the REEs through a 3-dimensional object, Round Top Mountain. The plots, however, only reveal variability in a single dimension, the vertical location or depth in the mountain of each sample. For the other two dimensions, two additional sets of graphs could present each sample in its east-west location (on the vertical graph axis) and then in its north-south location. But as can be seen from the graphs, there is so little variation of values of each element that significant geographic variation is not possible. Further, if, say, the values in a specific drill hole were higher than in others we would see a vertically oriented set of circles of a single color (each drill hole is 


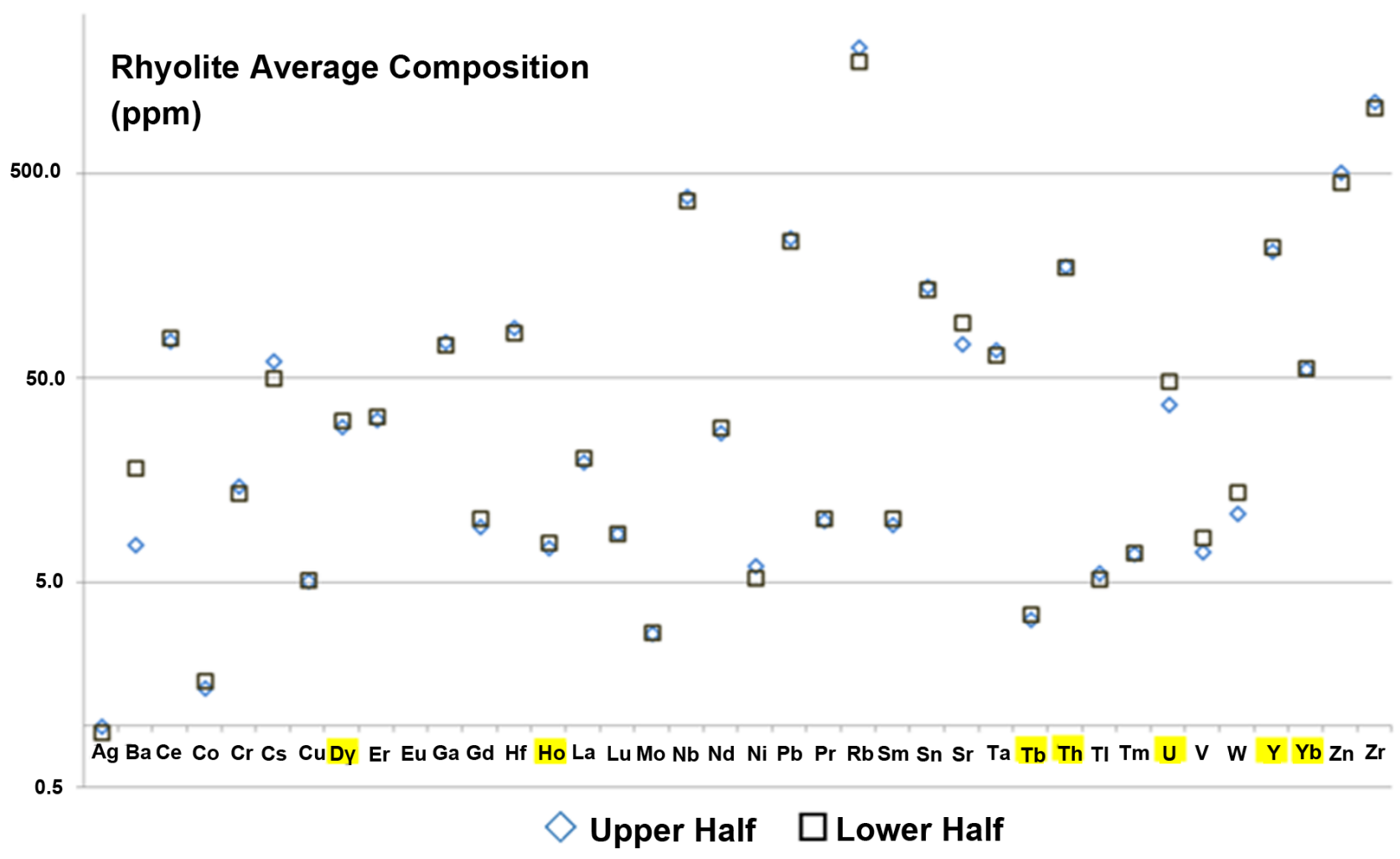

Figure 5. Plot of average concentration ( $\mathrm{ppm}$ ) of 38 minor and trace elements in the upper and lower halves of the Round Top Mountain rhyolite. Yellow highlights elements of mining significance. Note overlap or near-overlap of upper and lower laccolith values for nearly all elements. Very slight enrichment of some of the REEs in the lower half is evident (box symbol aligned slightly above diamond symbol). 
the rhyolite laccolith [20] [21] [31] [32] [33]. Thus an even grade is not just an oddity of the REEs, but reflects the well-mixed nature of the deposit itself.

This point is confirmed in Figure 5, although comparison of elemental averages in just upper and lower sections of the rhyolite is less strong evidence than the comparison of well over a thousand samples in Figures 2-4. Note that the suite of 38 elements includes incompatible elements, some of which are incorporated in the major mineralogy of the deposit (e.g., Rb, a large-ion lithophile element (LILE), resides chiefly in the potassium feldspar substituting for the $\mathrm{K}$ cations) and those that are concentrated in the late-stage minor minerals such as the high field strength elements (HFSE), including the REEs, Nb, Ta, U, Zr, etc. Because Figure 5 includes elements incorporated in both early- and late-stage crystallization of the laccolith, it supports a model of thorough mixing of the magma at all stages of cooling.

We have no explanation for the one noticeable anomaly, seen for Ba; most likely it is present as a post-laccolith vein or fracture deposit. In any event it is not a target economic element.

\subsection{Significance}

The figures demonstrate, with high reliability, the even grade of the target YHREEs as well as the LREEs through the majority of the deposit. Given the geologic setting and the nature and cooling-crystallization processes of a laccolith intrusion it is reasonable to assume that the even grade characterizes REE distribution in the portions of the deposit not included in the extensive drilled and sampled region.

Previous study has shown that: 1) yttrofluorite hosts nearly all of the REEs at Round Top; and 2) the yttrofluorite grains are very fine, few larger than $10 \mu \mathrm{m}$ in dimension, with most only a few $\mu \mathrm{m}$ or less in size [20] [21] [31] [32] [33] [34]. This fine grain size makes extraction via conventional froth flotation prohibitively expensive due to the extreme grinding and milling required to release the minuscule yttrofluorite grains from their enclosing gangue matrix. Because of the porosity of the rhyolite and its largely insoluble composition (90\% - 95\% feldspar and quartz) heap leaching of 3- to 4-cm chunks releases up to $90 \%$ of YHREEs in laboratory experiments. The small grain size of the yttrofluorite and its pervasive distribution are related to the posited deposition from a fluorine-rich carrier fluid, the last remnant of the parent magma [20] [21] [31] [32] [33]. This carrier, likely a supercritical fluid, permeated the entire laccolith, and cooled to yield the remarkably even distribution of yttrofluorite and other minor minerals rich in incompatible elements. The data in Figure 5 are consistent with this model of thorough magma mixing and pervasive final phase homogeneous deposition of incompatible elements.

From a mining standpoint, this consistent grade is a very positive feature of the deposit. As discussed earlier, estimation of the total amount of HREEs available for potential mining is greatly simplified, compared to, say, a mineralized 
vein deposit. The feedstock for the leach pad would have a near-constant HREE content for the life of the mine. All processing could be optimized during the earliest operations, yielding great savings in potential operating costs over time. From an investment point of view, the constant grade is a very positive feature of the Round Top deposit.

\subsection{Remaining Issues and Future Studies}

From an economic standpoint there is already enough material whose composition is well constrained by past drilling at Round Top to accommodate many decades of mining. Nonetheless, since the drilling programs concentrated their efforts on one side of the mountain, it would be interesting from a scientific standpoint to increase this coverage. That would assist in additional geological and geochemical studies to develop better models of the nature, timing, and sequence of mineralization. Such models would help in exploration for other examples of this currently unique and potentially quite valuable type of deposit [34].

\section{Conclusion}

Extensive elemental data make evident a remarkably consistent grade of mineralization for multiple trace and minor elements throughout the large sampled portion of the Round Top Mountain laccolith. Such homogeneity facilitates predictable and undeviating heap leach operation through many decades of mining, processing, and purifying the target YHREEs and byproduct elements. This exceptional feature adds to the potential economic value of Round Top Mountain.

\section{Acknowledgements}

The authors thank Texas Mineral Resources Corporation for access to proprietary technical data. This project was supported by joint research contracts 26-8211-12 and 26-8211-16 between TMRC and the University of Texas at El Paso. Funds to cover the costs to publish in open access were obtained from this source.

\section{Disclosure}

N.E.P. serves on the Board of Directors of TMRC. He is not and has never been an employee of TMRC, nor has he received any compensation from the research contracts that supported this research. J.W.C. received salary from UTEP via the joint research contracts to assist in this project. D.G. is the CEO of TMRC and serves on its Board of Directors. The funding sponsor had no role in the decision to publish the results.

\section{References}

[1] Chakmouradian, A.R. and Wall, F. (2012) Rare Earth Elements: Minerals, Mines, Magnets (and More). Elements, 8, 333-340. https://doi.org/10.2113/gselements.8.5.333

[2] Hatch, G. (2012) Dynamics in the Global Market for Rare Earths. Elements, 8, 341-346. 
https://doi.org/10.2113/gselements.8.5.341

[3] Massari, S. and Ruberti, M. (2013) Rare Earth Elements as Critical Raw Materials: Focus on International Markets and Future Strategies. Resources Policy, 38, 36-43. https://doi.org/10.1016/j.resourpol.2012.07.001

[4] US Geological Survey (2014) The Rare-Earth Elements-Vital to Modern Technologies and Lifestyles. USGS Publications Warehouse Fact Sheet 2014-3078, US Department of the Interior. https://pubs.usgs.gov/fs/2014/3078/pdf/fs2014-3078.pdf

[5] China Rare Earth Information Net. http://www.cre.net/Encre/index.asp

[6] Gholz, E. (2014) Rare Earth Elements and National Security. Council on Foreign Relations, New York. https://www.cfr.org/report/rare-earth-elements-and-national-security

[7] US General Accounting Office (GAO) (2016) Rare Earth Materials-Developing a Comprehensive Approach Could Help DOD Better Manage National Security Risks in the Supply Chain. Report to Congressional Committees. https://www.gao.gov/products/GAO-16-161

[8] Li, Y.-X., Zhang, L. and Zhou, X.-M. (2010) Protected Exploitation Model for Resource and Environment Ion-Type Rare Earth Deposit in Southern of China. Chinese Rare Earths.

http://en.cnki.com.cn/Article en/CJFDTOTAL-XTZZ201002023.htm

[9] Gao, Z.-Q. and Zhou, Q.-X. (2011) Contamination from Rare Earth Ore Strip Mining and Its Impacts on Resources and Eco-Environment. Chinese Journal of Ecology. http://en.cnki.com.cn/Article en/CJFDTotal-STXZ201112039.htm

[10] US Environmental Protection Agency (EPA) (2012) Rare Earth Elements: A Review of Production, Processing, Recycling, and Associated Environmental Issues. https://nepis.epa.gov/Exe/ZyNET.exe/P100EUBC.TXT?ZyActionD=ZyDocument\&Cl ient $=$ EPA $\&$ Index $=2011+$ Thru $+2015 \&$ Docs $=\&$ Query $=\&$ Time $=\&$ EndTime $=\&$ SearchM ethod $=1 \&$ TocRestrict $=$ n $\&$ Toc $=\&$ TocEntry $=\& Q$ Field $=\& Q$ FieldYear $=\&$ QFieldMonth $=$ $\underline{\& Q F i e l d D a y}=\& I n t Q F i e l d O p=0 \&$ ExtQFieldOp $=0 \& X m l Q u e r y=\&$ File $=D \% 3 \mathrm{~A} \% 5 \mathrm{Czyf}$ iles\%5CIndex\%20Data\%5C11thru15\%5CTxt\%5C00000005\%5CP100EUBC.txt\&Use $\underline{\mathrm{r}=\text { ANONYMOUS\&Password=anonymous\&SortMethod=h\%7C-\&MaximumDocu }}$ ments $=1 \&$ FuzzyDegree $=0 \&$ ImageQuality $=$ r75g8/r75g8/x150y150g16/i425\&Display $=$ hpfr\&DefSeekPage $=\mathrm{x} \&$ SearchBack $=$ ZyActionL\&Back $=$ ZyActionS\&BackDesc $=$ Res ults\%20page\&MaximumPages $=1 \& Z y$ Entry $=1 \&$ SeekPage $=x \& Z y P U R$

[11] Hongqiao, L. (2016) The Bottleneck of a Low-carbon Future. China Dialogue. https://www.chinadialogue.net/article/show/single/en/9209-The-dark-side-of-renew able-energy

[12] Bloomberg News (2017) Rare Earth Metals Electrified by China's Illegal Mining Clean-Up.

https://www.bloomberg.com/news/articles/2017-09-07/rare-earth-metals-electrified -by-china-s-illegal-mining-clean-up

[13] Mariano, A.N. (1989) Economic Geology of Rare Earth Minerals. In: Lipin, B.R. and McKay, G.A., Eds., Geochemistry and Mineralogy of the Rare Earth Elements, Reviews in Mineralogy 21, Mineralogical Society of America, Washington DC, 309-337.

[14] Wu, C., Yuan, Z. and Bai, G. (1996) Rare Earth Deposits in China. In: Jones, A.P., Wall, F. and Williams, C.T., Eds., Rare Earth Minerals, Chemistry, Origin, and Ore Deposits, Mineralogical Society Series 7, Chapman and Hall, London, 281-310.

[15] Peishan, Z. Zhuming, Y., Kejie, T. and Xueming, Y. (1995) Mineralogy and Geology of Rare Earths in China. Science Press, Beijing. 
[16] Gupta, C.K. and Krishnamurthy, N. (2005) Extractive Metallurgy of Rare Earths. CRC Press, Boca Raton.

[17] Mariano, A.N. and Mariano Jr., A. (2012) Rare Earth Mining and Exploration in North America. Elements, 8, 369-376. https://doi.org/10.2113/gselements.8.5.369

[18] Yttrofluorite. Mindat.org. http://www.mindat.org/gallery.php? $\min =4371$

[19] Pingitore Jr., N.E., Clague, J.W. and Gorski, D. (2012) Round Top Mountain (Texas, USA), a Massive, Unique Y-Bearing-Fluorite-Hosted Heavy Rare Earth Element (HREE) Deposit. Journal of Rare Earths, 32, 90-96. https://doi.org/10.1016/S1002-0721(14)60037-5

[20] Rubin, J.N., Price, J.G., Henry, C.D. and Koppenaal, D.W. (1987) Cryolite-Bearing and Rare Metal-Enriched Rhyolite, Sierra Blanca Peaks, Hudspeth County, Texas. American Mineralogist, 72, 1122-1130.

[21] Price, J.G., Rubin, J.N., Henry, C.D., Pinkston, T.L., Tweedy, S.W. and Koppenaal, D.W. (1990) Rare-Metal Enriched Peraluminous Rhyolites in a Continental Arc, Sierra Blanca Area, Trans-Pecos Texas. Chemical Modification by Vapor-Phase Crystallization. GSA Special Papers, 246, 103-120. https://doi.org/10.1130/SPE246-p103

[22] Texas Mineral Resources Corporation. http://tmrcorp.com/

[23] Henry, C.D., McDowell, F.W., Price, J.G. and Smyth, R.C. (1986) Compilation of Potassium-Argon Ages of Tertiary Igneous Rocks, Trans-Pecos, Texas. University of Texas, Bureau of Economic Geology, Austin, 1-34. https://doi.org/10.23867/GC8602D

[24] Gustavson Associates (2013) NI 43-101 Preliminary Economic Assessment. Round Top Project, Sierra Blanca. http://tmrcorp.com/news/technical reports/

[25] Pingitore Jr., N.E., Clague, J.W. and Gorski, D. (2016) XRF Standardless Comparison of Mining Head and Tail Grades to Screen and Display Ore Processing Recoveries. American Journal of Analytical Chemistry, 7, 785-796.

http://www.scirp.org/JOURNAL/PaperInformation.aspx?PaperID=7180 https://doi.org/10.4236/ajac.2016.711070

[26] Negron, L., Pingitore, N. and Gorski, D. (2016) Porosity and Permeability of Round Top Mountain Rhyolite (Texas, USA) Favor Coarse Crush Size for Rare Earth Element Heap Leach. Minerals, 6, 16. http://www.mdpi.com/2075-163X/6/1/16

[27] National Research Council (2002) Evolutionary and Revolutionary Technologies for Mining. The National Academies Press, Washington DC.

[28] Luttrell, G.H. (2003) Density Separation: Are We Really Making Use of Existing Processing Engineering Knowledge? In: Honaker, R.Q. and Forrester, W.R., Eds., Advances in Gravity Separation, Society for Mining, Metallurgy, and Exploration, Inc., Littleton, 1-15.

[29] Wills, B.A. (2008) Mineral Processing Technology. 7th Edition, Butterworth-Heinemann, Amsterdam.

[30] Columbite: Columbite Mineral Information and Data. https://www.mindat.org/min-1112.html

[31] Elliott, B.A., O’Neill, L.C. and Kyle, J.R. (2017) Mineralogy and Crystallization History of a Highly Differentiated REE-Enriched Hypabyssal Rhyolite: Round Top Laccolith, Trans-Pecos, Texas. Mineralogy and Petrology, 111, 569-592.

[32] Pingitore Jr., N.E., Piranian, M., Amaya, M.A., Negron, L.M. and Gorski, D. (2015) Micro-Distribution of Heavy Rare Earth Elements in Round Top Mountain Rhyolite Deposit (Hudspeth County, Texas, USA) by EPMA Mapping. American Geo- 
physical Union, Fall Meeting, Abstract V23B-3130.

[33] Pingitore Jr., N.E., Piranian, M., Negron, L.M. and Gorski, D. (2018) Microprobe Mapping of Rare Earth Element Distribution in Round Top Yttrofluorite Deposit. Advances in Materials Physics and Chemistry.

[34] Jowitt, S.M., Medlin, C.C. and Cas, R.A.F. (2017) The Rare Earth Element (REE) Mineralisation Potential of Highly Fractionated Rhyolites: A Potential Low-Grade, Bulk Tonnage Source of Critical Metals. Ore Geology Reviews, 86, 548-562. https://doi.org/10.1016/j.oregeorev.2017.02.027 